\title{
Clonality in seagrasses, emergent properties and seagrass landscapes
}

\author{
Gary A. Kendrick ${ }^{1, *}$, Carlos M. Duarte ${ }^{2}$, Núria Marbà ${ }^{2}$ \\ ${ }^{1}$ School of Plant Biology, The University of Western Australia, 35 Stirling Highway, Crawley, Western Australia 6009, Australia \\ ${ }^{2}$ Instituto Mediterraneo de Estudios Avanzados, (IMEDEA, CSIC-UIB), Miquel Marques 21, 07190 Esporles Islas Baleares, Spain
}

\begin{abstract}
Seagrasses are clonal monocots that dominate shallow subtidal coastal and estuarine environments worldwide. They are important for their relatively high productivity and their role in coastal sediment stabilization, as habitat and food for invertebrates, fishes, turtles, dugongs and manatees, and as a source for detrital food webs. Seagrasses grow through the iteration of a vegetative ramet, consisting of leaves capable of photosynthesizing attached to a shoot, a portion of rhizome and associated roots. Seagrass research has in the past focused on either the study of growth of the ramet or changes of seagrass distributions over $1000 \mathrm{~s}$ of ha to $1000 \mathrm{~s}$ of $\mathrm{km}^{2}$. There has been little attempt to link these scales. Interestingly, growth and space occupation of both measured and modelled patches of seagrasses have been found to be faster than predicted from the growth and iteration, through branching, of ramets. Similarly, predicted radial spread of patches does not agree with observed changes in the distribution of seagrasses in shallow subtidal landscapes. This review assesses the links between growth of ramets and patches of seagrasses and the spread, infilling and distribution of seagrasses in shallow subtidal landscapes. We explore the potential that accelerated growth of patches and seagrass landscapes are an emergent property of ramet growth.
\end{abstract}

KEY WORDS: Seagrasses · Clonal growth · Ramets · Patch dynamics · Emergence · Subtidal landscapes Resale or republication not permitted without written consent of the publisher

\section{INTRODUCTION}

Seagrass meadows are highly productive ecosystems and cover between $1.5 \times 10^{5}$ and $6 \times 10^{5} \mathrm{~km}^{2}$ worldwide (Duarte \& Cebrián 1996, Green \& Short 2003). They account for a significant fraction of the carbon burial in the ocean (Duarte \& Cebrián 1996), and support highly diverse and productive food webs (summarized in Hemminga \& Duarte 2000). Seagrass meadows are, however, experiencing worldwide decline (Duarte 2002) under the effects of global climate change (Marbà \& Duarte 1997, Seddon et al. 2000) and human impacts (Short \& Wyllie-Echeverria 1996, Duarte 2002). The need to predict both loss and recovery of seagrasses is becoming a major social as well as resource management issue (Duarte 2002), yet the time scales involved in seagrass colonization are largely unknown. Further research is needed into the processes that control the horizontal spread of seagrasses, patch survival and growth, and dynamics of meadows within subtidal landscapes.

We have long assumed that the time scales of formation and dynamics of seagrass landscapes would be best understood from a detailed knowledge of seagrass clonal growth, yet there is growing evidence that expansion of seagrasses in the landscape is more than the sum of clonal growth of all individual shoots. Growth of seagrass patches and meadows accelerates as they increase in size (Vidondo et al. 1997, Marbà \& Duarte 1998, Kendrick et al. 1999, Sintes et al. 2005), 
suggesting non-linearity in the interactions between ramets. The faster growth of patches and meadows deserves specific attention, since it substantially affects our capacity to forecast meadow recovery from disturbance.

To clarify the terminology used in this review, we need to define a few basic terms. A seagrass ramet consists of a leaf-bearing shoot, portion of rhizome and roots. A landscape is a spatially heterogeneous area containing a group of classes. The term 'seagrass landscape' was coined by Robbins \& Bell (1994) and consists of 2 classes: seagrass and unvegetated sediments. Emergence is a product of coupled, context-dependent interactions between individuals (i.e. seagrass ramets) that are technically non-linear (Holland 1998). Holland (1998) stated that the rules governing these interactions '...generate the complexity, and the ever-changing flux of patterns that follows leads to perpetual novelty and emergence...'. For the purposes of this review, emergent landscape patterns are described as the speed of infilling and the spatial patterning of the class seagrass within a seagrass landscape that are generated by simple rules governing growth of individual ramets, but that are not directly predictable from the sum of growth of the total population of ramets.

The main objective of this paper is to review the evidence for emergence from growth of seagrass ramets, growth and survival of seagrass patches, and infilling rates and patterns of seagrasses in seagrass landscapes. To achieve this goal, we first review the existing literature on clonal growth of ramets, growth and survival of seagrass patches, and dynamics of seagrasses in seagrass landscapes. We then compare the approaches presently used in seagrass research with the more extensive literature on modelling clonal growth in terrestrial plants. We conclude with a framework for future research and modeling of the dynamics of seagrass landscapes.

\section{GROWTH OF SEAGRASS RAMETS}

Seagrasses are clonal organisms and occupy space by reiterating a basic unit, the ramet. The pattern of vegetative proliferation of seagrass ramets depends on elongation (i.e. rate of addition and size of rhizome internodes) and branching (i.e. branching frequency and branching angle) of the rhizome, and the rhizome length in between consecutive shoots (Bell \& Tomlinson 1980, Angevine \& Handel 1986, Cain et al. 1996). The variability in clonal growth of seagrasses can be expressed as interspecific differences in size and patterns of growth of the ramets, intraspecific variation associated with phenotypic plasticity, and undetermined variation including genotypic variation.
A large part of the variability in clonal growth within the seagrass flora is accounted for by allometric scaling to seagrass size (defined as rhizome diameter; Duarte 1991). Rhizome elongation rates, branching frequency and angles decline as size increases by the following relationships: elongation rate $=$ seagrass $\operatorname{size}^{-1.6}$; branching frequency $=$ seagrass size ${ }^{-1.6}$; and branching angle $=$ seagrass size $^{-0.3}$. These relationships only account for 58, 39 and $21 \%$ of interspecific variation in clonal growth, respectively (Marbà \& Duarte 1998). Allometric scaling has been interpreted to reflect construction costs (e.g. the cost of rhizome elongation increases by the square of its thickness).

Intraspecific variability in clonal growth is also substantial, and rhizome elongation rates, branching frequency and branching angles typically vary by approximately 72,34 and $36 \%$, respectively, within any one species (Marbà \& Duarte 1998). Growth of seagrass ramets responds to environment signals such as nutrients (Pérez et al. 1994), sediment inundation (Marbà \& Duarte 1994) and water movement (Jensen \& Bell 2001). Intraspecific variability in branching rate appears to be partly controlled by apical dominance, although experimental evidence is lacking for most species. In Cymodocea nodosa, growing rhizome apices have been experimentally shown to suppress branching within $50 \mathrm{~cm}$ distance of apices (Terrados et al. 1997). The intraspecific variability in rhizome elongation depends on space availability, as shown by greater extension rates in rhizome apices growing at the periphery of clones (i.e. runners) than those growing at their centres (Marbà \& Duarte 1998).

Seagrass clones are connected by rhizomes to neighbouring ramets, allowing locally acquired resources to be shared among ramets, thus integrating resources across larger spatial scales than those directly accessible to a single ramet (Libes \& Boudouresque 1987, Tomasko \& Dawes 1989). Across a range of species, resource translocation along rhizomes is generally in the direction of rhizome apices (Marbà et al. 2001). The response of ramet size to local resources, together with the integration of resources across the clone have been shown to result in emergent properties in clonal plants in general, and in particular the capacity of the clone to average out the local conditions (Pennings \& Callaway 2000).

\section{GROWTH OF SEAGRASS PATCHES}

Seagrass colonization proceeds through the growth of patches. Seagrass patches have size-specific mortality with greater mortalities in smaller patches (Duarte \& Sand-Jensen 1990, Olesen \& Sand-Jensen 1994, Vidondo et al. 1997, Ramage \& Schiel 1999). There 
appears to be a critical size after which patch mortality rates decline sharply. These results suggest that colonization rates should be enhanced by greater patch survival once patches exceed a critical size. Seagrasses are ecosystem engineers (sensu Jones et al. 1997), in that they are able to alter the environment they colonize, by increasing particle (Gacia \& Duarte 2001) and nutrient (Pedersen et al. 1997) retention, attenuating turbulence and waves, and affecting biogeochemical conditions and processes in the sediments (Holmer \& Nielsen 1997, Enríquez et al. 2001, Barrón et al. 2004). These changes lead to improved conditions for seagrass growth, which may further account for increased patch survival and accelerated patch growth with increasing patch size (Vidondo et al. 1997). In addition the perimeter-to-area ratio of the patches decreases with increasing patch size, thereby increasing withinpatch accumulation of resources available to support patch growth (Marbà et al. 2001).

Seagrass patches grow through the development of rhizome networks from the originating seedling or plant as well as new rhizome networks contributed by recruitment of new seedlings to the patch. Hence, the growth of seagrass patches should be able to be predicted from growth of ramets, as discussed above. Modelling of seagrass clonal networks using only rhizome elongation and branching (rate and angle of branches) has revealed emergent patterns, in the form of non-linear growth by patches that cannot be readily predicted from growth of individual ramets (Marbà \& Duarte 1998, Sintes et al. 2005). In particular, the model of Marbà \& Duarte (1998) indicated that branching results in accelerated occupation of space by clones. The area occupied by the modelled clone increased, for all species simulated, as time cubed, instead of time squared as would be expected from linear growth of rhizomes. This acceleration developed as a consequence of the dominance of branching processes over linear growth of rhizomes as the clonal network, or patch, grews larger. Furthermore, the rate of space occupation by the patch was closely dependent on branching angles: acute angles resulted in greater space occupation for a specific rhizome network length than broad angles. More recent, sophisticated models have explained this non-linear behaviour as the result of a shift in growth of the rhizome network from a diffuse-limited initial stage where the patch is an open network of rhizomes, to a compact growth stage where the patch has a high density of ramets and spreads radially (Sintes et al. 2005). The evidence that the rate of patch growth accelerates with patch size in natural populations for Cymodocea nodosa (Duarte \& SandJensen 1990, Vidondo et al. 1997) is consistent with findings of accelerated extension rates derived from these models of rhizome networks (Marbà \& Duarte
1998, Sintes et al. in press). Hence, the growth of seagrass patches should not be modelled as a constant radiative process (sensu Duarte 1995).

\section{GAPS IN MEADOWS SHOW SIMILAR DYNAMICS TO SEAGRASS PATCHES}

Evolution of gaps in meadows have been described for a range of seagrass species. For example, gaps within Halodule wrightii meadows (Florida, USA) can develop and infill again in $<6$ mo for small gaps $\left(<30 \mathrm{~m}^{2}\right)$ and $\geq 1.5 \mathrm{yr}$ for large gaps $\left(>30 \mathrm{~m}^{2} ;\right.$ Bell et al. 1999). The size distribution of gaps was skewed towards small-sized gaps in Bell et al.'s (1999) study, much like those described for patches (Vidondo et al. 1997). The rate of gap infilling in $H$. wrightii beds is faster than for most seagrass species. For example, Thalassia hemprichii grew into experimental $0.25 \mathrm{~m}^{2}$ gaps over $2 \mathrm{yr}$, but the slow-growing Enhalus acoriodes was predicted to take $10 \mathrm{yr}$ to infill these gaps (Rollon et al. 1998). Infilling of approximately $1000 \mathrm{~m}^{2}$ circular gaps by the temperate seagrass Posidonia australis was predicted to take between 65 and $100 \mathrm{yr}$ (Meehan \& West 2000). Hastings et al. (1995) found that gaps $<25 \mathrm{~m}^{2}$ in $P$. sinuosa meadows in Western Australia infilled over $50 \mathrm{yr}$ but that larger gaps remained, suggesting the evolution of an alternate stable state, the sand gap, within these meadows.

Can we relate these observations of gap evolution to that of patch evolution? The rates of infilling are similar to those of patch expansion, but infilling is spatially restricted by shoot density: as gaps get smaller there are more spreading horizontal apices and vertical shoots per unit area. The rates of infilling of gaps have not been modelled, but this would be a productive area for future research.

\section{CHANGE IN SEAGRASS LANDSCAPES}

Seagrass landscape dynamics have generally been described by mapping historical change in seagrass distributions (e.g. Larkum \& West 1990, Quammen \& Onuf 1993, Short \& Burdick 1996, Kendrick et al. 2000, 2002, Seddon et al. 2000, Fredericksen et al. 2004). These mapping exercises document change in seagrass distribution and cover over time, but generally do not associate mapped changes with the underlying processes generating that change, and rarely correlate spatial changes in seagrass landscapes with environmental factors. Fonseca \& Bell (1998), Robbins \& Bell (2000) and Fredericksen et al. (2004b) have attempted to link spatial changes in seagrass landscapes to environmental factors. Seagrass mapping studies have 
demonstrated that landscapes are dynamic over decadal time scales. Seagrass losses have been correlated to increased human development in the coastal zone (Larkum \& West 1990, Short \& Burdick 1996, Kendrick et al. 2002) or to natural phenomena (Seddon et al. 2000). A few mapping studies have demonstrated widespread increases in seagrass cover in fast-growing (Quammen \& Onuf 1993) and slow-growing seagrass species (Kendrick et al. 2000).

Tropical seagrasses can vary in both their distribution and coverage between seasons and years. Robbins $\&$ Bell (2000) described the dynamics of a 5 ha subtidal seagrass landscape in Tampa Bay, Florida. In this landscape, 2 species of seagrass interacted: Halodule wrightii and Thalassia testudinum. Seagrass cover increased by $14 \%$ between spring 1994 and fall 1995, with changes occurring at the edges of existing patches, suggesting that rhizome elongation was mostly responsible for increase in seagrass cover.

Slower-growing temperate seagrasses are dynamic over decadal time scales. Kendrick et al. (1999) described changing seagrass landscapes on Success Bank, Western Australia, over 21 yr. We analyzed 4 ha landscape units, selected from areas of Posidonia coriacea and Amphibolis griffithii meadows, for seagrass cover from aerial photographs from 1972, 1982 and 1993. Seagrass cover in landscape units increased by $50 \%$ (from 2 to 3 ha) between 1972 and 1993. Seagrass expansion was evident as an increase in the number and size of seagrass patches. Different emergent patterns were observed in seagrass landscapes, ranging from honeycomb-shaped meadows to spotted distributions of seagrass patches (Kendrick et al. 2000).

As well as growth, seagrass patch size and distribution have been demonstrated to change under different hydrodynamic conditions (Fonseca \& Bell 1998, Robbins \& Bell 2000). Fonseca \& Bell (1998) developed a predictive model of seagrass bed development from an index of relative wave exposure and tidal currents. Their study area consisted of continuous to widely dispersed patches of Zostera marina and Halodule wrightii along a gradient in increasing hydrodynamic activity near Beaufort, North Carolina, USA. There was an abrupt transition at $50 \%$ coverage of seagrasses, which was the transition where landscape elements joined or occurred as discrete elements. These correlated with current speeds that initiated movement of sand grains at the sediment surface, and a relatively high exposure to wind waves. Fonseca \& Bell (1998) concluded that local seagrass pattern can be predicted from their physical setting. Robbins \& Bell (2000) also concluded that the hydrodynamics, specifically winter storms, which influence large-scale features such as sediment transport and wind direction and fetch area are major forcing factors for seagrass patch growth and emergent patterns in seagrass landscapes.

\section{MODELLING EMERGENCE IN TERRESTRIAL CLONAL PLANTS}

Clonal growth is not only restricted to seagrasses, but is also widespread among terrestrial plants. Landscape modelling has been used to study genet and ramet survival (Inghe 1989), the adaptive nature of clonal growth rules (Oborny 1994), clonal integration (Oborny et al. 2000), and the advantage of clonal growth over seedling establishment in patchy environments (Hiebeler 2000). All these studies have used individual-based, discrete-event, spatially explicit models, visualized as cellular automata.

The emergent clonal plant landscapes have been heavily influenced by differences in clonal growth and clonal integration (Inghe 1989, Oborny 1994) combined with the effect of frequency and scale of disturbance or environmental patchiness (Inghe 1989, Hiebeler 2000). These models have shown that spatial interactions between individuals can influence population dynamics and the emergent spatial distribution of clonal plants in landscapes, even if the environment is homogeneous (e.g. Harada \& Isawa 1994). For example, emergence of landscape pattern from local interactions in plants has been modelled for vegetative pattern in semi-arid grazed environments (Hille Ris Lambers et al. 2001), where vegetation is distributed as irregular patches to regular bands or stripes of vegetation with a scale of 100s of metres (Hiernaux \& Gerárd 1999). Hille Ris Lambers et al. (2001) found that a positive feedback between plant density and water filtration could account for these structures. Therefore, the use of individual-based complex systems modelling developed for understanding emergent properties of clonal growth in terrestrial plants, if applied to seagrass, could assist us to more fully understand the relationships between relatively simple growth of ramets, accelerated patch development and emergence of repeated and stable patterns observed in seagrass landscapes.

\section{CONCLUSIONS AND A NEW FRAMEWORK}

Seagrass landscape studies have focused on describing changes in seagrass distributions and associating these changes with the physical environment. In contrast, studies of terrestrial clonal plants have approached landscapes by an assessment of the advantage, both ecological and evolutionary, of clonal architecture and integration on the persistence of 
clonal plants in landscapes. For seagrass landscapes, little effort has been made to assess the influence of local interactions between individual ramets on distribution of seagrasses (notable exceptions are the studies of Marbà \& Duarte 1998, and Sintes et al. 2005), although this is a relatively new and highly productive area of research for terrestrial clonal plants (Oborny 1994, Oborny et al. 2000).

Seagrass morphology may respond to the hydrodynamic setting or other environmental conditions in a way that may influence the distribution of seagrass patches and meadows. For example, linear bed forms can develop for Posidonia coriacea and P. sinuosa (Cambridge 1975, G. A. Kendrick pers. obs.), Cymodocea nodosa (Marbà \& Duarte 1994) and Zostera marina (Fonseca \& Bell 1998) under extreme waveforcing. Physical setting and hydrodynamic forcing have been used to predict seagrass bed shape and size (Fonseca \& Bell 1998, Robbins \& Bell 2000). Can seagrass bed forms be used to predict physical setting and hydrodynamic forcing? There is a positive feedback mechanism between seagrass growth and the physical environment (Fonseca \& Bell 1998). While disturbance plays a significant role in structuring the shape and size of seagrass beds (Fonseca \& Bell 1998), architectural responses by the seagrasses also contribute (Fonseca \& Bell 1998). In specific environments where the frequency of disturbance is great enough to reset the process of colonization (sensu Fonseca \& Bell 1998), these emergent features of seagrass distribution will remain visible in the subtidal landscape.

At present we describe landscape-scale modifications to seagrasses by mapping losses and gains in seagrass distribution, without studying the underlying processes that drove these changes. Linkages need to be made between growth and survivorship of ramets and patches and these descriptions of seagrass landscapes. We propose spatially explicit landscape modelling as a framework to revealing the underlying dynamics behind emergence of patterns in seagrass landscapes, much as they are presently being used to study terrestrial clonal plants.

Acknowledgements. Funding was from an Australian Research Council Discovery grant (DP345856) to G.A.K., and by European Commission contracts \# ERB3514PL972504 and EVK3-CT-2000-00044 and Spanish contract REN2000-2123-E to N.M. and C.M.D.

\section{LITERATURE CITED}

Angevine MW, Handel SN (1986) Invasion of forest floor space, clonal architecture, and population growth in the perennial herb Clitonia borealis. J Ecol 74:547-560

Barrón C, Marbà N, Terrados J, Kennedy H, Duarte CM
(2004) Community metabolism and carbon budget along a gradient of seagrass (Cymodocea nodosa) colonization. Limnol Oceanogr 49:1642-1651

Bell AD, Tomlinson PB (1980) Adaptive architecture in rhizomatous plants. Bot J Lin Soc 80:125-160

Bell SS, Robbins BD, Jensen SL (1999) Gap dynamics in a seagrass landscape. Ecosystems 2:493-504

Cain ML, Dudle KA, Evans JP (1996) Spatial models of foraging in clonal plant species. Am J Bot 83:76-85

Cambridge ML (1975) Seagrasses of south-western Australia with special reference to the ecology of Posidonia australis Hook f. in a polluted environment. Aquat Bot 1:149-162

Duarte CM (1991) Allometric scaling of seagrass form and productivity. Mar Ecol Prog Ser 77:289-300

Duarte CM (1995) Submerged aquatic vegetation in relation to different nutrient regimes. Ophelia 41:87-112

Duarte CM (2002) The future of seagrass meadows. Environ Conserv 29:192-206

Duarte CM, Cebrián J (1996) The fate of marine autotrophic production. Limnol Oceanogr 41:1758-1766

Duarte CM, Sand-Jensen K (1990) Seagrass colonization: patch formation and patch growth in Cymodocea nodosa. Mar Ecol Prog Ser 65:193-200

Enríquez S, Marbá N, Duarte CM, van Tussenbroek B, Reyes G (2001) Effects of seagrass (Thalassia testudinum) on sediment redox. Mar Ecol Prog Ser 219:149-158

Fonseca MS, Bell SS (1998) Influence of physical setting on seagrass landscapes near Beaufort, North Carolina, USA. Mar Ecol Prog Ser 171:109-121

Frederiksen M, Krause-Jensen D, Holmer M, Laursen JS (2004a) Spatial and temporal variation in eelgrass (Zostera marina) landscapes: influence of physical setting. Aquat Bot 78:147-165

Frederiksen M, Krause-Jensen D, Holmer M, Laursen JS (2004b) Long-term changes in area distribution of eelgrass (Zostera marina) in Danish coastal waters. Aquat Bot 78: $167-181$

Gacia E, Duarte CM (2001) Sediment retention by a Mediterranean Posidonia oceanica meadow: the balance between deposition and resuspension. Estuar Coast Shelf Sci 52: 505-514

Green EP, Short FT (2003) World atlas of seagrasses. University of California Press, Berkeley, CA

Harada Y, Isawa Y (1994) Lattice population dynamics for plants with dispersing seeds and vegetative propagation. Res Popul Ecol 36:237-249

Hastings K, Hesp P, Kendrick GA (1995) Seagrass loss associated with boat moorings at Rottnest Island, Western Australia. Ocean Coast Manag 26:225-246

Hemminga M, Duarte CM (2000) Seagrass ecology. Cambridge Univiversity Press, Cambridge

Hiebeler D (2000) Populations on fragmented landscapes with spatially structured heterogeneities: landscape generation and local dispersal. Ecology 81:1629-1641

Hiernaux P, Gérard B (1999) The influence of vegetation pattern on productivity, diversity and stability of vegetation: the case of 'brousse tigré' in the Sahel. Acta Oecol 20: $147-158$

Hille Ris Lambers R, Rietkerk M, Van den Bosch F, Prins HHT, de Kroon H (2001) Vegetation pattern formation in semiarid grazing systems. Ecology 82:50-61

Holland JH (1998) Emergence: from chaos to order. Perseus Books, Reading, MA

Holmer M, Nielsen SL (1997) Sediment sulfur dynamics related to biomass-density pattern in Zostera marina (eelgrass) beds. Mar Ecol Prog Ser 146:163-171

Inghe O (1989) Genet and ramet survivorship under different 
mortality regimes - a cellular automata model. J Theor Biol 138:257-270

Jensen S, Bell S (2001) Seagrass growth and patch dynamics; cross-scale morphological plasticity. Plant Ecol 155: 201-217

Jones CG, Lawton JH, Schachak M (1997) Positive and negative effects of organisms as physical ecosystem engineers. Ecology 78:1946-1957

Kendrick GA, Eckersley J, Walker DI (1999) Landscape-scale changes in seagrass distribution over time: a case study from Success Bank, Western Australia. Aquat Bot 65: 293-309

Kendrick GA, Hegge BJ, Wyllie A, Davidson A, Lord DA (2000) Changes in seagrass cover on Success and Parmelia Banks, Western Australia between 1965 and 1995. Estuar Coast Shelf Sci 50:341-353

Kendrick GA, Aylward MJ, Hegge BJ, Cambridge ML, Hillman K, Wyllie A, Lord DA (2002) Changes in seagrass coverage in Cockburn Sound, Western Australia between 1967 and 1999. Aquat Bot 73:75-87

Larkum AWD, West RJ (1990) Long-term changes of seagrass meadows in Botany Bay, Australia. Aquat Bot 37:55-70

Libes M, Boudouresque CF (1987) Uptake and long-distance transport of carbon in the marine phanerogam Posidonia oceanica. Mar Ecol Prog Ser 38:177-186

Marbà N, Duarte CM (1994) Growth response of the seagrass Cymodocea nodosa to experimental burial and erosion. Mar Ecol Prog Ser 107:307-311

Marbà N, Duarte CM (1997) Interannual changes in seagrass (Posidonia oceanica) growth and environmental change in the Spanish Mediterranean littoral. Limnol Oceanogr 42: $800-810$

Marbà N, Duarte CM (1998) Rhizome elongation and seagrass clonal growth. Mar Ecol Prog Ser 174:269-280

Marbà N, Hemminga MA, Mateo MA, Duarte CM, Mass YEM, Terrados J, Gacia E (2001) Carbon and nitrogen translocation between seagrass ramets. Mar Ecol Prog Ser 226:287-300

Meehan AJ, West RJ (2000) Recovery time of a damaged Posidonia australis bed in south eastern Australia. Aquat Bot 67:161-167

Oborny B (1994) Growth rules in clonal plants and environmental predictability a simulation study. J Ecol 82:341-351

Oborny B, Kun A, Czaran T, Bokros S (2000) The effect of clonal integration on plant competition for mosaic habitat space. Ecology 81:3291-304

Olesen B, Sand-Jensen K (1994) Patch dynamics of eelgrass Zostera marina. Mar Ecol Prog Ser 106:144-156

Pedersen MF, Duarte CM, Cebrián J (1997) Rate of changes in

Editorial responsibility: Otto Kinne (Editor-in-Chief),

Oldendorf/Luhe, Germany organic matter and nutrient stocks during seagrass Cymodocea nodosa colonization and stand development. Mar Ecol Prog Ser 159:29-36

Pennings SC, Callaway RM (2000) The advantages of clonal integration under different ecological conditions: a community wide test. Ecology 81:709-716

Pérez M, Duarte CM, Romero J, Sand-Jensen K, Alcoverro T (1994) Growth plasticity in Cymodocea nodosa stands: the importance of nutrient supply. Aquat Bot 47:249-264

Quammen ML, Onuf CP (1993) Laguna Madre: seagrass changes continue decades after salinity reduction. Estuaries 16:302-310

Ramage DL, Schiel DR (1999) Patch dynamics and response to disturbance of the seagrass Zostera novazelandica on intertidal platforms in southern New Zealand. Mar Ecol Prog Ser 189:275-288

Robbins BD, Bell SS (1994) Seagrass landscapes: a terrestrial approach to the marine subtidal environment. Trends Ecol Evol 9:301-304

Robbins BD, Bell SS (2000) dynamics of a subtidal seagrass landscape: seasonal and annual change in relation to water depth. Ecology 81:1193-1205

Rollon RN, De Ruyter Van Steveninck ED, Van Vierssen W, Fortes MD (1998) Contrasting recolonization strategies in multi-species seagrass meadows. Mar Pollut Bull 37: 450-459

Seddon S, Connolly RM, Edyvane KS (2000) Large-scale seagrass dieback in northern Spencer Gulf, South Australia. Aquat Bot 66:297-310

Short FT, Burdick DM (1996) Quantifying eelgrass habitat loss in relation to housing development and nitrogen loading in Waquoit Bay, Massachusetts. Estuaries 19:730-739

Short FT, Wyllie-Echeverria S (1996) Natural and humaninduced disturbance of seagrasses. Environ Conserv 23: $17-27$

Sintes T, Marbà N, Duarte CM, Kendrick G (2005) Non-linear processes in seagrass colonisation explained by simple clonal growth rules. Oikos 108:165-175

Terrados J, Duarte CM, Kenworthy WJ (1997) Experimental evidence for apical dominance in the seagrass Cymodocea nodosa (Ucria) Ascherson. Mar Ecol Prog Ser 147:263-268

Tomasko DA, Dawes CJ (1989) Evidence for physiological integration between shaded and unshaded short shoots of Thalassia testudinum. Mar Ecol Prog Ser 54:299-305

Vidondo B, Duarte CM, Middelboe AL, Stefansen K, Lützen T, Nielsen SL (1997) Dynamics of a landscape mosaic: size and age distributions, growth and demography of seagrass Cymodocea nodosa patches. Mar Ecol Prog Ser 158: 131-138

Submitted: January 27, 2004; Accepted: November 9, 2004 Proofs received from author(s): March 22, 2005 